\title{
State-private partnership - the growth factor of gasification of Russian region
}

\author{
Irina Filimonova ${ }^{1,2, *}$, Anna Komarova $^{1,2}$, Vasily Nemov $^{1,2}$, Irina Provornaya ${ }^{1,2}$ and Yuri Dzyuba $a^{1,2}$ \\ ${ }^{1}$ Trofimuk Institute of Petroleum Geology and Geophysics SB RAS, 3, Koptug, 630090, Novosibirsk, Russia \\ ${ }^{2}$ Novosibirsk State University, 1, Pirogova, 630090, Novosibirsk, Russia
}

\begin{abstract}
The gasification of Russian regions is one of the most important problems for the national economy. The development of the gas supply system contributes to the socio-economic development of the regional economy, to the increase increasing the level and quality of life, and to the solution of the key environmental issues. The Krasnoyarskiy Kray is the only region in the east of the country that has a significant resource potential of natural gas but at the same time, it can't be connected to the trunk gas pipeline in the short and long term perspective. The purpose of the study is to assess the efficiency of investments in the construction of gas supply facilities, gasification, and their exploitation in the southern and central regions of the Krasnoyarskiy Kray. In this study authors solved the following objectives: we systematized information about the current state of the Krasnoyarskiy Kray gasification and the prerequisites for its development (resource base and transport infrastructure); we assessed economic efficiency of the investments in the construction, gasification, and exploitation of gas supply facilities in the southern and central regions of the Krasnoyarskiy Kray; we formulated proposals to ensure economic efficiency using the mechanism of public-private partnership. The authors recommend an option according to which federal budget investments will amount to $70 \%$ of their total investment in the Krasnoyarskiy Kray gasification program. Under this option, the selling price of gas will drop to 4708 rubles per 1000 cubic meters of natural gas excluding VAT. Organization of production, preparation for transport, and transportation of natural gas in the central regions of the Krasnoyarskiy Kray will create new highly paid jobs, significantly increase the GRP, and improve the demographic situation.
\end{abstract}

\section{Introduction}

Gasification of Russian regions is one of the most important tasks named by V.V. Putin in the annual message of the Russian Federation President to the Federal Assembly on January 15, 2020 [1]. The development of the gas supply system contributes to the socio-economic development of the regional economy, to the increase increasing the level and quality of life, and to the solution of the key environmental issues. Gasification of the regions in the east of the country will strengthen the energy security of the territories and create the basis for the development of equal trade relations with the countries of the Asia-Pacific region (APR).

The preconditions for increasing the level of gas supply of Russian regions are the presence of the world's largest natural gas reserves, and the high production and export rates of gas resources. The main factor that hinders the development of gasification in the region (primarily in the east of the country) is the absence of trunk gas pipelines and gas pipelines-branches for organizing gas supplies to settlements and industrial facilities [2].
Thus, the level of gasification in Russia on average in 2019 was around $70 \%$, and it should reach $90 \%$ in 2030 , following the General Scheme for the Development of the Gas Industry until 2030 [3-5]. However, the gasification of the regions is extremely uneven. The European part regions of the country are being gasified at a faster pace, while in the Eastern Siberia and the Far East regions the level of gasification is significantly lower than the average gasification values in the country. Also, in some regions, full-scale gasification programs have not yet begun. At the same time, the construction and commissioning of the Power of Siberia gas trunkline (December 2, 2019) had a positive impact on the development of gas supply in the east of the country. The gas pipeline route passes through the territory of five constituent entities of the Russian Federation - the Republic of Sakha (Yakutia), the Amurskaya Oblast', the Jewish Autonomous Oblast', the Khabarovsky Kray, and from 2023 through the territory of the Irkutskaya Oblast' [6-7].

Thus, the Krasnoyarskiy Kray is the only region in the east of the country that has a significant resource potential of natural gas [8]. Nevertheless, it can't be connected to the trunk gas pipeline in the short and long term perspective. The significant and negative feature of

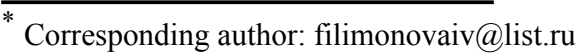


the socio-economic situation in the Krasnoyarskiy Kray is the extremely tense ecological situation in the main industrial centers [9-10]. One of the goals of this territory gasification should be improving the current situation.

The purpose of the study is to assess the efficiency of investments in the construction of gas supply facilities, gasification, and their exploitation in the southern and central regions of the Krasnoyarskiy Kray. To achieve this goal, we set the following objectives: we systematized information about the current state of the Krasnoyarskiy Kray gasification and the prerequisites for its development (resource base and transport infrastructure); we assessed economic efficiency of the investments in the construction, gasification, and exploitation of gas supply facilities in the southern and central regions of the Krasnoyarskiy Kray; we formulated proposals to ensure economic efficiency using the mechanism of public-private partnership.

The basis for the development of the gas transmission system in the east of the country was the completion of the Power of Siberia gas pipeline at the end of 2019. The gas pipeline has been laid across five constituent entities of the Russian Federation - Irkutsk and Amur Oblas', the Jewish Autonomous Oblast', the Republic of Sakha (Yakutia), and the Khabarovsky Kray region. The "Power of Siberia" route is laid along the existing oil trunk pipeline "Eastern Siberia - Pacific Ocean". At present, this allows significant savings in infrastructure and energy supply costs. In the future, it helps to organize the sale of natural gas from already developed oil and gas fields, which now supply oil to the ESPO and are experiencing problems with the commercial development of gas potential. The distance between the two pipelines ranges from $700 \mathrm{~m}$ to $17 \mathrm{~km}$. The total length of the gas pipeline is about $3000 \mathrm{~km}$, and the design capacity is 38 billion cubic meters of gas per year.

\section{Resource base and transport infrastructure as the basis for efficient gasification}

\subsection{The current state of Krasnoyarskiy Kray gasification}

On the territory of the Krasnoyarskiy Kray, network natural gas is currently supplied only to Norilsk and the Norilsk industrial hub. Gas supply to other consumers of the region is carried out according to autonomous schemes due to liquefied petroleum gas (LPG). LPG is a mixture of light hydrocarbons liquefied under pressure. The main components of LPG are propane and butane.

According to the established procedure, the gasification program for the Krasnoyarskiy Kray must be implemented by the General Scheme for Gas Supply and Gasification of the Krasnoyarskiy Kray developed and approved by the Administration of the region and by the PJSC "Gazprom". These programs were developed and approved in 2009 and 2016. Table 1 shows a comparative analysis of these two gas supply and gasification programs for the Krasnoyarskiy Kray region. The table shows that in 2009-2015 the general scheme of gasification and gas supply of the Krasnoyarskiy Kray was almost not implemented.

Moreover, for some indicators (the number of gas distribution stations, the number of gasified settlements, the number of the population served by gas, the number of gasified households and apartments, etc.), the General Scheme of 2016 provides for the value of target indicators that are significantly lower than in the 2009 scheme. It should be noted that the General Scheme provides for the construction of gas distribution networks, gas branch pipelines, inter-settlement gas pipelines and does not provide for the construction of the trunk gas pipeline. Therefore, the development of a new General Scheme, synchronized in time with strategic documents for the development of the energy and oil and gas industry of Russia and coordinated in terms of funding at the state and corporate levels, is relevant and timely.

Table 1. Comparative analysis of gas supply and gasification schemes for the Krasnoyarskiy Kray according to the General Schemes of 2009 and 2016.

\begin{tabular}{|c|c|c|}
\hline \multirow{2}{*}{ Index } & \multicolumn{2}{|c|}{ General Schemes, year } \\
\cline { 2 - 3 } & 2009 & 2016 \\
\hline $\begin{array}{c}\text { Number of gas distribution } \\
\text { stations, units }\end{array}$ & 19 & 12 \\
\hline $\begin{array}{c}\text { Length of gas pipeline branch, } \\
\text { thousand km }\end{array}$ & 61.8 & 61.8 \\
\hline $\begin{array}{c}\text { Length of inter-settlement gas } \\
\text { pipelines, km }\end{array}$ & 3012.3 & 3130.1 \\
\hline $\begin{array}{c}\text { Number of gasified settlements, } \\
\text { units }\end{array}$ & 415 & 396 \\
\hline $\begin{array}{c}\text { Population served by gas, } \\
\text { thousand people }\end{array}$ & 1567.0 & 480.0 \\
\hline $\begin{array}{c}\text { Number of gasified households } \\
\text { (apartments), thousand units }\end{array}$ & 603.5 & 207.4 \\
\hline $\begin{array}{c}\text { Total annual consumption, } \\
\text { million cubic meters m }\end{array}$ & 3637.2 & 3398.1 \\
\hline $\begin{array}{c}\text { including: population, } \\
\text { million cubic meters }\end{array}$ & 542.4 & 413.7 \\
\hline
\end{tabular}

\subsection{Resource base for gasification of the region}

The largest initial natural gas resources in the east of the country are in the Krasnoyarskiy Kray (Figure 1), which has concentrated about $60 \%$ of the gas potential of Eastern Siberia and the Republic of Sakha (Yakutia) (more than 28 trillion cubic meters). However, the region is characterized by the lowest degree of exploration $(4 \%)$ among the East Siberian regions, which is associated with the difficult geological structure of the deposits, the removal of subsoil use objects from potential consumers, and the lack of transport infrastructure.

Therefore, the share of industrial-grade reserves in the Krasnoyarskiy Kray is only $20 \%$ of the region's reserves as a whole. The largest deposits of the region in terms of total reserves of natural gas are Yurubcheno- 
Tokhomskoye, Pelyatkinskoye, Tagulskoye, Sobinskoye and Kuyumbinskoye gas and oil, and gas-condensate fields.

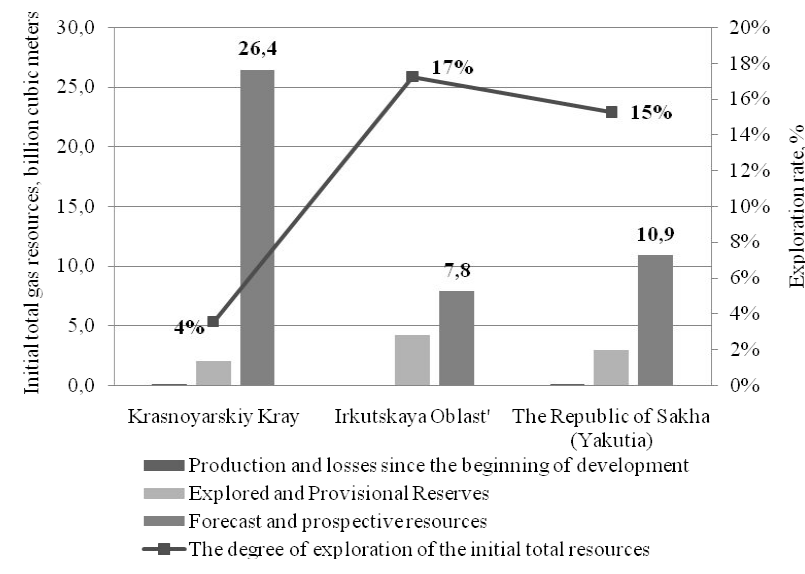

Fig. 1. The structure of the initial total gas resources in Eastern Siberia and in the Republic of Sakha (Yakutia).

In the Krasnoyarskiy Kray region, gas production in 2019 amounted to 12.8 trillion cubic meters, which is $9.0 \%$ more than the level of gas production in 2018 . Associated petroleum gas (APG) prevails in the structure of gas production in the Krasnoyarskiy Kray. The growth of its production is associated with the active development of oil fields after the commissioning in 2008 of the trunk oil pipeline "Eastern Siberia - Pacific Ocean". In the period 2017-2019, the growth in gas production in the region is associated with the intensive development of the Yurubcheno-Tokhomskoye and Kuyumbinskoye fields and, as a result, an increase in associated petroleum gas production. At the end of 2019, gas production at the fields increased by 2.3 billion cubic meters. Most of the gas is injected back into the reservoir to maintain reservoir pressure to increase the oil recovery factor and minimize the impact on the environment.

A decline in associated gas production was noted at the Vankor field, which is at a declining stage of oil production. Thus the volume of gas production at the field is 3.7 billion cubic meters lower now than at its peak in 2015. The Suzunskoye and Lodochnoye fields are located in the immediate vicinity. And on the border with the Turukhansk district in the Taimyr DolganNenets municipal district situated the Tagulskoye field. These fields have been consistently brought into development during the past three years and maintain the level of APG production in the Krasnoyarskiy Kray.

Free gas is produced within the local gas supply system based on the Pelyatkinskoye and SeveroSoleninskoye fields in the north of the Krasnoyarskiy Kray. Gas production in 2019 amounted to 2.8 billion cubic meters. In the Norilsk industrial region, gas is supplied for the needs of the energy sector, including the generation of heat and electricity. The main gas consumers are JSC Norilsk-Taimyr Energy Company, enterprises of the Polar Division of PJSC MMC Norilsk Nickel, and the city of Dudinka. There is no gas supply to the population, since earlier, during the construction of urban infrastructure, it had been agreed to use electric stoves in households. The household needs of the population are met through centralized power supply and heat supply to housing.

Traditionally, the main gasification of the country's territory was the trunk pipeline system. The main gas transportation system in Russia is the Unified Gas Supply System with an endpoint in the east of the country in the village. Proskokovo (Kemerovskaya oblast'). That is why the level of gasification in the regions of Eastern Siberia and the Far East (about $10.0 \%$ ) is almost seven times lower than the national average level $(68.5 \%)$. Due to the absence of main transport infrastructure in the east of the country, several local gas supply systems have been formed, including in the north of the Krasnoyarskiy Kray region.

Until now, a unified gas transmission system has not been formed in the East Siberian region, which hinders the development of gas fields already prepared for exploitation. In these conditions, subsoil users independently construct gas supply pipelines that provide gasification of individual settlements and industrial enterprises. The gas supply system and operation of gas transportation facilities in the region are located in the production area of JSC Norilskgazprom, JSC Taimyrgaz, and JSC Norilsktransgaz (not included in the PJSC Gazprom group). Gas transportation through the Pelyatkinskoye gas condensate field - SeveroSoleninskoye gas condensate field - YuzhnoSoleninskoye gas condensate field - Messoyakhskoye gas field - Norilsk is carried out by Norilsktransgaz. The length of the gas pipeline is $300 \mathrm{~km}$. Most of it passes through the territory of the Krasnoyarskiy Kray.

The basis for the development of the gas transmission system in the east of the country was the completion of the Power of Siberia gas pipeline at the end of 2019. The gas pipeline has been laid across five constituent entities of the Russian Federation - Irkutsk and Amur Oblas', the Jewish Autonomous Oblast', the Republic of Sakha (Yakutia), and the Khabarovsky Kray region. The "Power of Siberia" route is laid along the existing oil trunk pipeline "Eastern Siberia - Pacific Ocean". At present, this allows significant savings in infrastructure and energy supply costs. In the future, it helps to organize the sale of natural gas from already developed oil and gas fields, which now supply oil to the ESPO and are experiencing problems with the commercial development of gas potential. The distance between the two pipelines ranges from $700 \mathrm{~m}$ to $17 \mathrm{~km}$. The total length of the gas pipeline is about $3000 \mathrm{~km}$, and the design capacity is 38 billion cubic meters of gas per year.

The Chayandinskoye field in the Republic of Sakha (Yakutia) and the Kovyktinskoye field in the Irkutsk Oblast' have been laid down as the resource base for the "Power of Siberia" gas pipeline in the short term. The connection to the gas pipeline of the fields of the Krasnoyarskiy Kray has been postponed for the long term, which acts as a limiting factor in the development of gasification of the Krasnoyarskiy Kray according to the scheme of connection to the trunk pipeline system. 


\section{Methodology for assessing the effectiveness of the gasification program}

\subsection{Schematic diagram of gasification of the Krasnoyarskiy Kray}

Long-term prospects for gasification of the Krasnoyarskiy Kray are associated with the construction of branches from the Unified Gas Supply System (UGSS) in the area of the Proskokovo compressor station of the Kemerovo Region or the Volodino compressor station of the promising "Power of Siberia$2 "$ gas pipeline, and with the formation of new gas production centers in the Krasnoyarskiy Kray itself at the base of deposits of the Evenki municipal and Boguchansky regions. The Sobinskoye oil and gas condensate field, which is large in terms of gas reserves, located in the Tungusko-Chunsky district of the Evenki municipal district, can become the basis for the formation of such a gasification center. The operator of the field is Gazprom Ltd Geologorazvedka, which is part of PJSC Gazprom.

The initial plan until 2023 for the preparation of gasification in the south of the Krasnoyarskiy Kray includes additional exploration and the start of the development of fields in the Evenk regional and Boguchansky districts; the beginning of the creation of the Krasnoyarsk gas transmission system with the trunk gas pipeline "Sobinskoye oil and gas condensate field Boguchany - Achinsk - Krasnoyarsk".

After 2023, it is planned to transfer a significant part of the utility sector and boiler houses to LNG. Also, the action plan includes the use of natural gas in transport in the form of compressed natural gas (CNG) from 2020. In Krasnoyarsk, in 2020-2021, it is planned to purchase 50 units of a bus fleet that will operate on this CNG. After 2023, similar activities will be carried out in other cities and districts of the region.

\subsection{Algorithm for calculating the economic efficiency of the implementation of the gasification scheme of the Krasnoyarskiy Kray}

Assessment of the economic efficiency of gas supply and gasification projects is based on the methodology for evaluating the effectiveness of investment projects, developed by the Methodological Recommendations for Evaluating the Efficiency of Investment Projects (approved by order of the Ministry of Economic Development of Russia, the Ministry of Finance of Russia and Gosstroy of Russia No. VK 477 dated June 21, 1999).

The calculation of the costs for the construction of the trunk gas pipeline was carried out based on the aggregated figures of JSC Gazprom promgaz. According to the current practice in economic assessments, the program defines a list of gas supply and gasification facilities, and proposes the sequence of their construction, taking into account the geographical location and reserves of the selected natural gas sources.
The taxation system is adopted by the Tax Code of the Russian Federation, and the distribution of taxes paid by the budgets of various levels is following the Budget Code of the Russian Federation.

To assess efficiency, according to the recommendations, we use indicators that characterize commercial and budgetary efficiency (Table 2).

Table 2. Economic Performance Indicators.

\begin{tabular}{|c|c|c|}
\hline Definition & Formula & Criterion \\
\hline $\begin{array}{c}\text { Net present } \\
\text { value }\end{array}$ & $N P V=\sum_{t=1}^{T} \frac{N P_{t}+D_{t}-C_{t}}{(1+r)^{t}}$ & $N P V>0$ \\
\hline $\begin{array}{c}\text { Internal rate } \\
\text { of return }\end{array}$ & $I R R=r^{*}: N P V_{t}\left(r^{*}\right)=0$ & $I R R>r$ \\
\hline $\begin{array}{c}\text { Profitabilityin } \\
\text { dex }\end{array}$ & $P I=\frac{\sum_{t=1}^{T} \frac{N P_{t}+D_{t}}{(1+r)^{t}}}{\sum_{t=1}^{T} \frac{C_{t}}{(1+r)^{t}}}$ & $P I>1$ \\
\hline $\begin{array}{c}\text { Discounted } \\
\text { payback } \\
\text { period }\end{array}$ & $D P P=t^{*}: \sum_{t=1}^{t^{*}} N P V_{t}=0$ & min \\
\hline $\begin{array}{c}\text { Budgetefficie } \\
\text { ncy }\end{array}$ & $B E=\sum_{t=1}^{T} \frac{T a x_{t}}{(1+r)^{t}}$ & $B E>0$ \\
\hline
\end{tabular}

where $N P_{t}-$ net profit; $D_{t}-$ depreciation; $C_{t}-$ capital investment; $r$ - discount rate; $\operatorname{Tax}_{t}-$ taxes and fees.

\subsection{Public-private partnership mechanism}

The sources and mechanisms of financing regional gasification programs in the Russian Federation are defined by Article 17. "Legal framework for the development of gasification of the territories of the Russian Federation" Federal Law No. 69 "On gas supply in the Russian Federation". According to this article, financing of regional gasification programs for housing and communal services, industrial and other organizations can be carried out through:

federal budget funds;

budgets of the respective constituent entities of the Russian Federation;

other sources not prohibited by the legislation of the Russian Federation.

Based on the existing practice in Russia, PJSC Gazprom expands the concept of "other sources not prohibited by the legislation of the Russian Federation" and understands by them:

investments of PJSC Gazprom within the framework of its programs;

funds of enterprises - promising gas consumers; public funds for the construction of internal gas pipelines, the purchase of gas equipment, installation of equipment; gas distribution company funds; 
other mechanisms of investment and attraction of investments in the development of the regional gas market not prohibited by the legislation of the Russian Federation.

Therefore, when forecasting funding sources, the Gas Supply Programs for the Krasnoyarskiy Kray included, together with PJSC Gazprom, PJSC Rosneft, PJSC MMC Norilsk Nickel, RN-Vankor, AO Norilskgazprom, JSC Norilsktransgaz, JSC Taimyrgaz. This list can be expanded during the implementation of the program.

To increase the efficiency of the gasification program implementation, the mechanism of public-private partnership was taken into account. The federal budget is supposed to finance part of capital investments in gasification of the Krasnoyarskiy Kray. Ten options have been developed and evaluated, where the share of state participation varies from $0 \%$ to $100 \%$ in $10 \%$ increments.

\section{Results and discussion}

According to our calculations, the development of gas supply and gasification of the Krasnoyarskiy Kray is economically efficient at the sale price of natural gas excluding VAT - 6125 rubles per 1000 cubic meters. This scenario assumes the development of gas fields in the Boguchansky and Evenkiysky municipal districts with the technological schemes of development adopted by Gazprom VNIIGaz and JSC Gazprom promgaz, gas transportation through the predicted pipeline infrastructure and its implementation to end consumers under the established price and tax conditions in the option when all these investments are made by PJSC Gazprom. The calculations were made for the period up to 2050 , taking into account a discount rate of $10 \%$.

We took the internal rate of return (IRR) of PJSC Gazprom's investments as an efficiency criterion when evaluating the project. The project is considered profitable if the IRR of the investment is not lower than the initial threshold value. According to the concept of JSC Gazprom's participation in the gasification of the regions of the Russian Federation (approved on November 30, 2009), the required level of return on investments must be at least $12 \%$.

No other region of the Russian Federation has such a high gas price. For example, let us point out that the minimum level of wholesale prices for natural gas excluding VAT varies in the regions of the Russian Federation under consideration as of July 1, 2020, from RUB 4105 to RUB 4792 per 1,000 cubic meters.

In terms of the average monthly wages of the population, the Krasnoyarskiy Kray is in 20th place among the subjects of the Russian Federation. The average monthly salary in 2019 in the Krasnoyarskiy Kray was about 35 thousand rubles. In the central and southern regions of the region, it is significantly lower.

With a gas selling price of 6125 rubles per 1000 cubic meters, excluding VAT, network gas will not be able to compete with brown coal, and the population will not be able to purchase such services.
To reduce the selling price of gas, we considered options for the federal budget to participate in financing the gas supply and gasification system in the central and southern regions of the Krasnoyarskiy Kray region.

When assessing the budgetary efficiency of the federal budget for the extractive industries as a whole, it should be borne in mind that the Krasnoyarskiy Kray ranks first in the Russian Federation in the production of gold, platinoids, nickel, lead, and one of the first in oil (fourth) and copper production. Thus, if we take into account the revenues to the federal budget of enterprises of all these extractive industries, then the actual efficiency of budget investments in the economy of the Krasnoyarskiy Kray will be higher.

We considered several options in which the federal budget contribution varied from 0 to $90 \%$. In these options, the selling price of gas without VAT will vary from 6125 rubles of gas to 4380 rubles per 1000 cubic meters of gas. In the program, we recommend focusing on the option according to which the federal budget investments in the objects of PJSC Gazprom's responsibility will amount to $70 \%$ of their total amount. Under this option, the selling price of gas without VAT will be 4708 rubles per 1000 cubic meters of natural gas (Table 3 ).

Table 3. Economic efficiency indicators.

\begin{tabular}{|c|c|}
\hline Index & Values \\
\hline Source of financing & $100 \%$ \\
\hline Federal budget & $70 \%$ \\
\hline PJSC Gazprom & $30 \%$ \\
\hline $\begin{array}{l}\text { Sales price including VAT, rubles / thousand } \\
\text { cubic meters }\end{array}$ & 5650 \\
\hline $\begin{array}{l}\text { Sales price excluding VAT, rubles / thousand } \\
\text { cubic meters }\end{array}$ & 4708 \\
\hline $\begin{array}{l}\text { Natural gas consumption, } \\
\text { million cubic meters / year }\end{array}$ & 8150 \\
\hline $\begin{array}{l}\text { Natural gas consumption, million cubic } \\
\text { meters }\end{array}$ & 165650 \\
\hline Sales proceeds, million rubles & 935923 \\
\hline Capital investments, million rubles & 28525 \\
\hline Operating costs, million rubles & 746162 \\
\hline Taxes, million rubles & 180673 \\
\hline Federal budget & 152091 \\
\hline Regional budget & 16214 \\
\hline Local budget & 12368 \\
\hline Net profit, million rubles & 9087 \\
\hline Cash flow, million rubles & 66828 \\
\hline Net present value (NPV), million rubles & 2947 \\
\hline Internal rate of return (IRR), $\%$ & $12 \%$ \\
\hline Discounted payback period, years & 22 \\
\hline
\end{tabular}

According to the recommended option, by 2050, due to the payment of taxes based on the results of the gas supply and gasification system in the central and southern regions of the Krasnoyarskiy Kray, investments from the federal budget will be fully returned to the 
budget, and the GNI of budget investments (budgetary efficiency) will reach 7\%.

\section{Conclusion}

The implementation of the gasification program for the central and southern regions of the Krasnoyarskiy Kray will provide a significant contribution to the economic and social development of the Krasnoyarskiy Kray in several areas:

a new large gas production center will be formed in Eastern Siberia, which will allow gasification of the central and southern regions of the Krasnoyarskiy Kray, the Republic of Khakassia and the Republic of Tyva;

the implementation of the program will ensure that the budgets of all levels for 2024-2050 will receive at least 176148 billion rubles, the budget efficiency of the program will exceed $7 \%$;

due to the gasification of power plants, boiler houses, automobile transport in large cities (Krasnoyarsk, Achinsk, Kansk), the ecological situation in the central and southern regions of the Krasnoyarsk Territory will improve, and at the enterprises of the energy and metallurgical complexes will increase the life expectancy and improve the quality of life of the population.

The research was carried out with financial support from the grants of the President of the Russian Federation No. MK1459.2019.6, No. NSh-2571.2020.6 and the RFBR grant No. 20-010-00699.

\section{References}

1. V.V. Putin Message from the President to the Federal Assembly. President of Russia (2020)

2. I.V. Filimonova, I.V. Provornaya, V.Yu. Nemov, S.I. Shumilova. Gas pipeline "Power of Siberia" - the basis for the formation of a new center of gas production and processing in the east of the country. Gas Industry 5 (784) (2019)

3. N.Yu. Spektor, A.S. Sarkisov Analysis of gasification of the Russian Federation. Problems of Economics and Management of the Oil and Gas Complex 5 (2015)

4. T.A. Bobyleva, A.S. Khripunova Research of problematic issues of gasification of Russia and methods of their solution. University Bulletin 7-8 (2016)

5. A.V. Belinsky. Impact of gas supply and gasification on the economic growth of Russian regions (econometric approach). Gas industry 6 (2018)

6. A.M. Karasevich, Yu.N. Yarygin, Yu.V. Drozdov Expansion of gas supply sources during gasification of Russian regions. Gas industry 14 (2009)
7. N.Yu. Spector. State of gasification and analysis of use of various energy resources in the Russian Federation. Oil, gas and business 6 (2017)

8. A.E. Kontorovich, L.V. Eder, I.V. Filimonova. Paradigm oil and gas complex of Russia at the present stage. IOP Conference Series: Earth and Environmental Science 84(1) (2017)

9. I.V. Filimonova; L.V. Eder; M.V. Mishenin; T.M. Mamakhatov. Current state and problems of integrated development of mineral resources base in Russia. IOP Conference Series: Earth and Environmental Science 84(1) (2017)

10. I.V. Filimonova, I.V. Provornaya, S.I. Shumilova, E.A. Zemnukhova. Cluster analysis of Russian oil companies based on tax burden parameters. Journal of Tax Reform 5(1) (2019) 